\section{Stereoselective Synthesis of Cytotoxic Anhydrophytosphingosine Pachastrissamine (Jaspine B) from D-Xylose}

\author{
Yuguo Du, ${ }^{*}, \dagger$ Jun Liu, ${ }^{\dagger}$ and Robert J. Linhardt*,* \\ State Key Laboratory of Environmental Chemistry and \\ Ecotoxicology, Research Center for Eco-Environmental \\ Sciences, Chinese Academy of Sciences, Beijing 100085, China, \\ and Departments of Chemistry, Biology, and Chemical and \\ Biological Engineering, Rensselaer Polytechnic Institute,
} Troy, New York 12180

duyuguo@mail.rcees.ac.cn

Received August 5, 2005

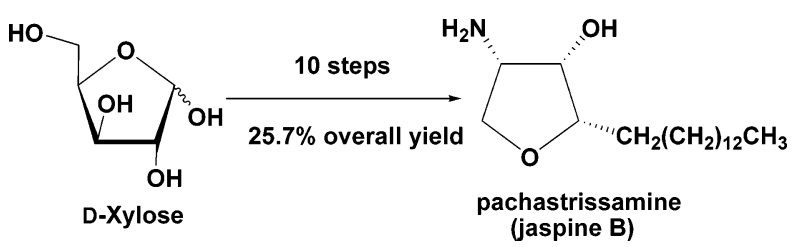

The first naturally occurring anhydrophytosphingosine, pachastrissamine (jaspine B), a marine compound cytotoxic toward P388, A549, HT29, and MEL28 cell lines at $\mathrm{IC}_{50}=$ $0.01 \mu \mathrm{g} / \mathrm{mL}$ level, has been stereoselectively synthesized from D-xylose in 10 linear steps with $25.7 \%$ overall yield.

Pachastrissamine (1, Figure 1) is a natural occurring anhydrophytosphingosine derivative, first isolated in 2002 by Higa and co-workers ${ }^{1}$ from the Okinawa marine sponge Pachastrissa sp. (family Calthropellidae). Bioassay-guided separation of the sponge crude oil led to pure $\mathbf{1}$, which exhibited a significant cytotoxicity of $0.01 \mu \mathrm{g} / \mathrm{mL}$ against P388, A549, HT29, and MEL28 cell lines. Almost at the same time, Debitus and coworkers ${ }^{2}$ investigated the cytotoxicity of ethanolic extract $\left(\mathrm{IC}_{95}\right.$ $=10 \mu \mathrm{g} / \mathrm{mL}, \mathrm{KB}$ cell line) from a new species of Jaspis, a marine sponge collected in Vanuatu, and the bioguided fractionation of this extract using a brine shrimp bioassay led to two cytotoxic compounds, named as jaspine A (2, Figure 1) and jaspine B (1, Figure 1). Jaspine B hydrochloride displayed remarkable bioactivity $\left(\mathrm{IC}_{50}=0.24 \mu \mathrm{M}\right)$ against the $\mathrm{A} 549$ human lung carcinoma cell line using the ATPlite assay and represented the most potent anticancer agent on this cell line yet isolated from the Jaspis genus. High-resolution NMR, mass spectral analysis, and chemical derivatization studies suggested that the structure of pachastrissamine and jaspine $B$ were identical, i.e., an all-syn trisubstituted tetrahedrofuran framework and the $(2 S, 3 S, 4 S)$ absolute configuration.

$\dagger$ Chinese Academy of Sciences.

\$ Rensselaer Polytechnic Institute.

(1) Kuroda, I.; Musman, M.; Ohtani, I. I.; Ichiba, T.; Tanaka, J.; Cravalos, D. C.; Higa, T. J. Nat. Prod. 2002, 65, 1505-1506.

(2) Ledroit, V.; Debitus, C.; Lavaud, C.; Massiot, G. Tetrahedron Lett. 2003, 44, 225-228
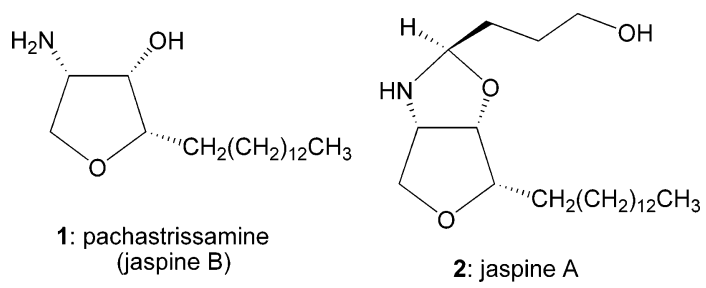

FIGURE 1. Structure of natural anhydrophytosphingosine pachastrissamine (jaspine B).

SCHEME 1. Retrosynthetic Analysis of Pachastrissamine (1)
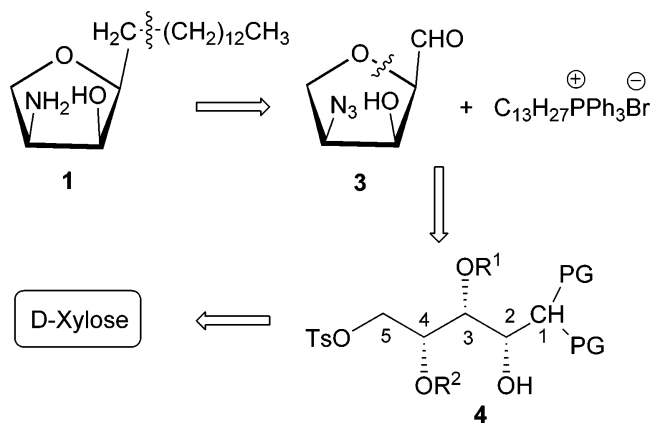

It has been reported that sphingosine 1-phosphate induces a rapid and relevant release of arachidonic acid and increases phospholipase D activity in A549 cells. $^{3}$ To improve our understanding of this anhydrosphingosine targeting to tumor cells and explore more potent analogues based on this novel structure, we launched a stereoselective total synthesis of natural pachastrissamine (jaspine B). During our efforts, two synthetic communications ${ }^{4,5}$ aimed to the total synthesis of pachastrissamine (jaspine B) using L-serine as starting material were published. In Rao's work, ${ }^{4}$ a diastereoisomeric mixture of $\mathbf{1}$ was formed, using a standard asymmetric synthesis, in 10 steps and $15.4 \%$ overall yield. In Datta's letter, ${ }^{5}$ enantiopure 1 was prepared through a bicyclic lactone intermediate in 14 steps and $15.5 \%$ overall yield from L-serine. Here, we report the stereoselective total synthesis of pachastrissamine (jaspine B).

Pachastrissamine 1 can be retrosynthetically disconnected into a formylfuran derivative $\mathbf{3}$ and a commercially available alkyl Wittig reagent. The furan structure of $\mathbf{3}$ can be derived from 2,5-ring closure of an acyclic intermediate 4 , which can be easily prepared from natural D-xylose through suitable functional group transformations (Scheme 1).

D-Xylose treated with concentrated $\mathrm{H}_{2} \mathrm{SO}_{4}$ in acetone ${ }^{6}$ gave 1,2-acetal $\mathbf{5}$ in $82 \%$ yield (Scheme 2). Regioselective tosylation of $\mathbf{5}$ on the primary alcohol with tosylimidazolide, MeOTf, and $\mathrm{N}$-methylimidazole in THF at $0{ }^{\circ} \mathrm{C}$ afforded 6 in excellent yield. ${ }^{7}$

(3) (a) Vasta, V.; Meacci, E.; Catarzi, S.; Donati, C.; Farnararo, M.; Bruni, P. Biochim. Biophys. Acta 2000, 1483, 154-160. (b) Meacci, E.; Vasta, V.; Moorman, J. P.; Bobak, D. A.; Bruni, P.; Moss, J.; Vaughan, M. J. Biol. Chem. 1999, 274, 18605-18612.

(4) Sudhakar, N.; Kumar, A. R.; Prabhakar, A.; Jagadeesh, B.; Rao, B. V. Tetrahedron Lett. 2005, 46, 325-327.

(5) (a) Bhaket, P.; Morris, K.; Stauffer, C. S.; Datta, A. Org. Lett. 2005 , 7, 875-876. (b) Bhaket, P.; Stauffer, C. S.; Datta, A. J. Org. Chem. 2004, $69,8594-8601$.

(6) Moravcova, J.; Capkova, J.; Stanek, J. Carbohydr. Res. 1994, 263, $61-66$.

(7) Gerspacher, M.; Rapoport, H. J. Org. Chem. 1991, 56, 3700-3706. 
SCHEME 2. Attempted Synthesis toward Pachastrissamine $(\mathbf{1})^{a}$

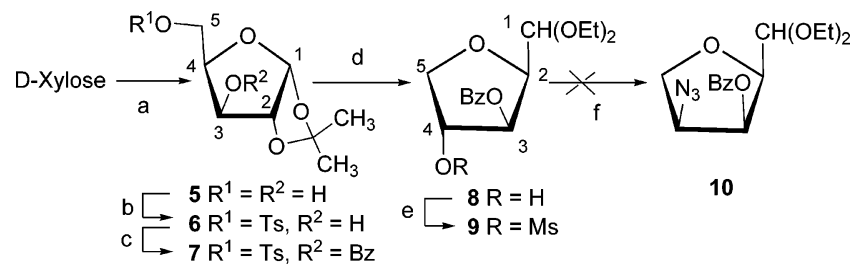

${ }^{a}$ Reagents and conditions: (a) concd $\mathrm{H}_{2} \mathrm{SO}_{4}$, acetone, then $\mathrm{Na}_{2} \mathrm{CO}_{3}, 82 \%$; (b) tosylimidazolide, MeOTf, $N$-methylimidazole, THF, $93 \%$; (c) $\mathrm{BzCl}$, pyridine, rt, $5 \mathrm{~h}, 96 \%$; (d) $5 \%$ hydrochloric acid in ethanol (v/v), reflux, 3 h, $90 \%$; (e) $\mathrm{MsCl}$, pyridine, rt, 4 h, $99.4 \%$; (f) $\mathrm{NaN}_{3}, \mathrm{NH}_{4} \mathrm{Cl}$, dry DMF, $60-120{ }^{\circ} \mathrm{C}, 5-15 \mathrm{~h}$.

Benzoylation of $\mathbf{6}(\rightarrow 7)$, followed by acid-catalyzed furan ring reconstruction in ethanol under reflux conditions, afforded the key intermediate, 2,5-anhydro-3-O-benzoylxylose diethylacetal (8), in $81 \%$ yield over three steps. The structure of $\mathbf{8}$ was confirmed by FABMS $\left[\mathrm{m} / \mathrm{z} 311(\mathrm{M}+\mathrm{H})^{+}\right]$and its ${ }^{1} \mathrm{H}-{ }^{1} \mathrm{H}$ COSY spectrum (chemical shift of $\mathrm{H}-1$ moved upfield from 5.85 to $4.76 \mathrm{ppm}$ ). Derivatization of $\mathbf{8}$ with acetic anhydride in pyridine resulted in the downfield movement of the peak corresponding to $\mathrm{H}-4(\delta: 4.33 \mathrm{ppm} \rightarrow 5.22 \mathrm{ppm})$ in the ${ }^{1} \mathrm{H}$ NMR spectrum, further confirming the structure of $\mathbf{8}$ (see the Supporting Information). To obtain the $S$-configuration required for the 4-amino group, the 4-OH of $\mathbf{8}$ was mesylated with methanesulfonyl chloride in pyridine $(\rightarrow 9)$, followed by an $\mathrm{S}_{\mathrm{N}} 2$ substitution using $\mathrm{NaN}_{3}$ in DMF. Unfortunately, extensive efforts failed to produce a good yield of desired compound $\mathbf{1 0}$, affording instead a rather complex mixture based on NMR analysis. A literature survey suggested that the 3,4-acyloxonium ion might be formed in our experiments leading to an inseparable mixture of $3 R-, 4 R$-, and $4 S$-azido-displaced products. ${ }^{8}$

A high yield of C-4 azido-displacement can be accomplished by protecting the hydroxyl group at C-3 through alkylation (Scheme 3) as in 11, instead of through acylation (Scheme 2) as in 9. The xylose derivative $\mathbf{6}$ was benzylated with benzyl trichloroacetimidate in the presence of TMSOTf $(\rightarrow \mathbf{1 1}) .{ }^{9}$ Acidcatalyzed furan ring reconstruction afforded 2,5-anhydro compound $\mathbf{1 2}$ in a yield of $89 \%$. Mesylation $(\rightarrow \mathbf{1 3})$ and azido substitution using sodium azide afforded the key enantiopure acetal 14 in $71 \%$ isolated yield over two steps. The acetal protection of $\mathbf{1 4}$ was removed with aqueous trifluroacetic acid to afford aldehyde $\mathbf{1 5} .^{10}$ Standard Wittig olefination of $\mathbf{1 5}$ with a C-13 alkyl donor resulted in the incorporation of an inseparable mixture of $E$ - and $Z$-isomers of the corresponding C-14 olefinic side chain. The $Z / E$ ratio was determined to be greater than 10:1 on the basis of ${ }^{1} \mathrm{H}$ NMR but both could be further reduced to the desired alkyl side chain (Scheme 3). In a single step, hydrogenation of azido, benzyl, and the side chain double bond furnished target molecule $\mathbf{1}$ in an excellent yield of $92 \%$.

In conclusion, the stereoselective total synthesis of a structurally unique bioactive anhydrosphingosine natural product has been achieved in 10 linear steps and $25.7 \%$ overall yield from an inexpensive natural product, D-xylose. This synthesis took advantage of D-xylose, a carbohydrate having a chiral template

(8) Hill, J.; Hough, L.; Richardson, A. C. Carbohydr. Res. 1968, 8, 7-18. (9) Nakajima, N.; Horita, K.; Abe, R.; Yonemitsu, O. Tetrahedron Lett. 1988, 29, 4139-4142.

(10) Ellison, R. A.; Lukenbach, E. R.; Chiu, C. W. Tetrahedron Lett. 1975, 29, 499-502.
SCHEME 3. Total Synthesis of Pachastrissamine (1)

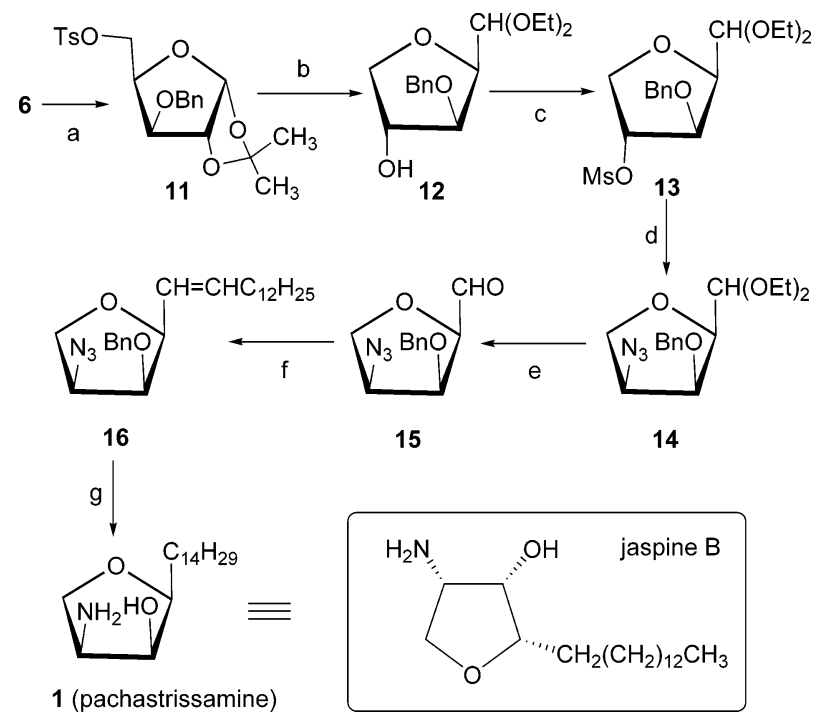

${ }^{a}$ Reagents and conditions: (a) benzyl trichloroacetimidate, $1 \mathrm{~mol} \%$ of TMSOTf, dry $\mathrm{CH}_{2} \mathrm{Cl}_{2},-40{ }^{\circ} \mathrm{C}, 75 \%$; (b) $5 \%$ hydrochloric acid in ethanol (v/v), reflux, 3 h, 89\%; (c) $\mathrm{MsCl}$, pyridine, rt, $4 \mathrm{~h}$; (d) $\mathrm{NaN}_{3}, \mathrm{NH}_{4} \mathrm{Cl}$, dry DMF, $120{ }^{\circ} \mathrm{C}, 20 \mathrm{~h}, 71 \%$ for two steps; (e) aqueous $50 \%$ trifluroacetic acid, $\mathrm{CH}_{2} \mathrm{Cl}_{2}$, room temperature, 30 min, $90 \%$; (f) $\mathrm{C}_{13} \mathrm{H}_{27} \mathrm{Ph}_{3} \mathrm{P}^{+} \mathrm{Br}^{-}$, BuLi, dry THF, $-40{ }^{\circ} \mathrm{C}, 86 \%, \mathrm{Z} / E>10 / 1 ;(\mathrm{g}) \mathrm{Pd}(\mathrm{OH})_{2} / \mathrm{C}, \mathrm{H}_{2}, \mathrm{MeOH} / \mathrm{EtOAc}$, $5 \mathrm{~h}, 92 \%$.

that could be modified through an acid-catalyzed 2,5-cyclization and $\mathrm{C}-3$ azido-substitution to fit the required $(2 S, 3 S, 4 S)$ configuration of the pachastrissamine target. As exemplified in this study, carbohydrate moieties provide versatile synthons in asymmetric synthesis of natural products. ${ }^{11}$ The present study should provide a valuable strategy for the preparation of other functionalized tetrahydrofuran derivatives, acyclic sphingosine analogues, carbasugars, and heterocyclic enzyme inhibitors. ${ }^{2,12}$

\section{Experimental Section}

3- $O$-Benzyl-1,2- $O$-isopropylidene-5- $O$-p-toluenesulfonyl- $\alpha$-Dxylofuranose (11). To a solution of compound 6 (104 $\mathrm{mg}, 0.3$ $\mathrm{mmol})$ and benzyl trichloroacetimidate $(142 \mathrm{mg}, 0.6 \mathrm{mmol})$ in dry $\mathrm{CH}_{2} \mathrm{Cl}_{2}(2 \mathrm{~mL})$ at $-40{ }^{\circ} \mathrm{C}$ was added TMSOTf $(1.1 \mu \mathrm{L}, 0.003$ mmol) under $\mathrm{N}_{2}$ protection. The reaction was monitored by TLC (2:1 EtOAc-petroleum ether) until all starting material was consumed and then quenched with $\mathrm{Et}_{3} \mathrm{~N}$ and concentrated to dryness. The residue was subjected to silica gel column chromatography (3:1 petroleum ether-EtOAc) to give $11(97 \mathrm{mg}, 75 \%)$ as a syrup: $[\alpha]^{25} \mathrm{D}-21\left(c 1.0, \mathrm{CHCl}_{3}\right) ;{ }^{1} \mathrm{H} \mathrm{NMR}(400 \mathrm{MHz}$,

(11) (a) Boons, G.-J.; Hale, K. J. Organic Synthesis with Carbohydrates; Sheffield Academic Press: Sheffield, England, 2000. (b) Elliott, M. C; Williams, E. J. Chem. Soc., Perkin Trans. 1 2001, 2303-2340. (c) Elliott, M. C. J. Chem. Soc., Perkin Trans. 1 2002, 2301-2323. (d) Harmange, J. C.; Figadere, B. Tetrahedron: Asymmetry 1993, 4, 1711-1754. (e) Ziegler, F. E.; Wang, Y. J. Org. Chem. 1998, 63, 426-427. (f) Carda, M.; Rodriguez, S.; Segovia, B.; Marco, J. A. J. Org. Chem. 2002, 67, 6560-6563.

(12) (a) Muralidhar, P.; Radhika, P.; Krishna, N.; Rao, D. V.; Rao, C. B. Nat. Prod. Sci. 2003, 9, 117-142. (b) O'Connell, P. W.; Tsien, S. H. Arch. Biochem. Biophys. 1959, 80, 289-294. (c) Sugiyama, S.; Honda, M.; Komori, T. Liebigs Ann. Chem. 1988, 619-625. (d) Birk, R.; Sandhoff, K.; Schmidt, R. R. Liebigs Ann. Chem. 1993, 71-75. (e) Jo, S. Y.; Kim, H. C.; Jeon, D. J.; Kim, H. R. Heterocycles 2001, 55, 1127-1132. (f) Bols, M. Acc. Chem. Res. 1998, 31, 1-8. (g) Asano, N.; Nash, R. J.; Molyneux, R. J.; Fleet, G. W. J. Tetrahedron: Asymmetry 2000, 11, 1645-1680. (h) Callam, C. S.; Lowary, T. L. J. Org. Chem. 2001, 66, 8961-8972. (i) Bleriot, Y.; Giroult, A.; Mallet, J.-M.; Rodriguez, E.; Vogel, P.; Sinay, P. Tetrahedron: Asymmetry 2002, 13, 2553-2565. 
$\left.\mathrm{CDCl}_{3}\right) \delta 1.25,1.43(2 \mathrm{~s}, 2 \times 3 \mathrm{H}), 2.41(\mathrm{~s}, 3 \mathrm{H}), 3.95(\mathrm{~d}, 1 \mathrm{H}, J=$ $3.3 \mathrm{~Hz}), 4.18(\mathrm{dd}, 1 \mathrm{H}, J=6.1,9.9 \mathrm{~Hz}), 4.30(\mathrm{dd}, 1 \mathrm{H}, J=6.1,9.9$ $\mathrm{Hz}), 4.35(\mathrm{dt}, 1 \mathrm{H}, J=3.3,6.1 \mathrm{~Hz}), 4.45(\mathrm{~d}, 1 \mathrm{H}, J=11.8 \mathrm{~Hz})$, $4.56(\mathrm{~d}, 1 \mathrm{H}, J=3.7 \mathrm{~Hz}), 4.60(\mathrm{~d}, 1 \mathrm{H}, J=11.8 \mathrm{~Hz}), 5.85(\mathrm{~d}, 1 \mathrm{H}$, $J=3.7 \mathrm{~Hz}), 7.23-7.25(\mathrm{~m}, 2 \mathrm{H}), 7.28-7.35(\mathrm{~m}, 5 \mathrm{H}), 7.76-7.78$ $(\mathrm{m}, 2 \mathrm{H}) ;{ }^{13} \mathrm{C}$ NMR $\left(100 \mathrm{MHz}, \mathrm{CDCl}_{3}\right) \delta 21.4,26.1,26.6,66.9$, 71.8, 77.4, 81.0, 81.8, 105.0, 111.9, 127.5, 127.8, 127.9, 128.3, 129.7, 132.5, 136.9, 144.8. Anal. Calcd for $\mathrm{C}_{22} \mathrm{H}_{26} \mathrm{O}_{7} \mathrm{~S}: \mathrm{C}, 60.81$; H, 6.03. Found: C, 61.09; H, 5.97.

2,5-Anhydro-3- $O$-benzyl- $\alpha$-D-xylose Diethyl Acetal (12). Compound $11(217 \mathrm{mg}, 0.5 \mathrm{mmol})$ was dissolved in anhydrous ethanol $(10 \mathrm{~mL})$ containing concentrated hydrochloric acid $(0.5 \mathrm{~mL})$. The mixture was stirred under reflux for $3 \mathrm{~h}$ and then neutralized with saturated aqueous sodium carbonate. The aqueous layer was extracted with EtOAc $(3 \times 20 \mathrm{~mL})$, and the combined organic phase was washed with brine, dried over $\mathrm{Na}_{2} \mathrm{SO}_{4}$, and concentrated under vacuum. Purification of the residue by silica gel column chromatography (1:1 petroleum ether-EtOAc) gave $\mathbf{1 2}$ as a syrup (131 mg, 89\%): $[\alpha]^{25} \mathrm{D}+77\left(c 0.7, \mathrm{CHCl}_{3}\right) ;{ }^{1} \mathrm{H} \mathrm{NMR}\left(400 \mathrm{MHz}, \mathrm{CDCl}_{3}\right)$ $\delta 1.18(\mathrm{t}, 3 \mathrm{H}, J=7.0 \mathrm{~Hz}), 1.24(\mathrm{t}, 3 \mathrm{H}, J=7.0 \mathrm{~Hz}), 1.67(\mathrm{br} \mathrm{s}$, $1 \mathrm{H}), 3.50-3.55(\mathrm{~m}, 1 \mathrm{H}), 3.67-3.80(\mathrm{~m}, 4 \mathrm{H}), 3.94(\mathrm{~d}, 1 \mathrm{H}, J=3.6$ $\mathrm{Hz}), 4.12(\mathrm{dd}, 1 \mathrm{H}, J=3.7,7.7 \mathrm{~Hz}), 4.20(\mathrm{dd}, 1 \mathrm{H}, J=4.0,9.9$ $\mathrm{Hz}), 4.33$ (br d, 1H, $J=3.9 \mathrm{~Hz}), 4.60,4.62(2 \mathrm{~d}, 2 \mathrm{H}, J=11.8 \mathrm{~Hz})$, $4.76(\mathrm{~d}, 1 \mathrm{H}, J=7.7 \mathrm{~Hz}), 7.26-7.37(\mathrm{~m}, 5 \mathrm{H}) ;{ }^{13} \mathrm{C} \mathrm{NMR}(100 \mathrm{MHz}$, $\left.\mathrm{CDCl}_{3}\right) \delta 15.2,15.3,61.5,63.0,72.2,74.2,74.4,79.7,84.2,100.5$, 127.4, 127.6, 128.3, 137.9. Anal. Calcd for $\mathrm{C}_{16} \mathrm{H}_{24} \mathrm{O}_{5}$ : C, 64.84; H, 8.16. Found: C, 65.09; H, 8.11.

2,5-Anhydro-3- $O$-benzyl-4- $O$-methanesulfonyl- $\alpha$-D-xylose Diethyl Acetal (13). To a solution of $12(70 \mathrm{mg}, 0.24 \mathrm{mmol})$ in pyridine $(2 \mathrm{~mL})$ was added methanesulfonyl chloride $(37 \mu \mathrm{L}, 0.48$ $\mathrm{mmol})$. The mixture was stirred at room temperature for $4 \mathrm{~h}$ and then coevaporated with toluene. The crude mesylate $\mathbf{1 3}$ was directly used in the next step without further purification. A small sample was purified on a silica gel column to get the physical data of 13: $\left[\alpha{ }^{25} \mathrm{D}+80\left(c 1.0, \mathrm{CHCl}_{3}\right) ;{ }^{1} \mathrm{H} \mathrm{NMR}\left(400 \mathrm{MHz}, \mathrm{CDCl}_{3}\right) \delta 1.16(\mathrm{t}\right.$, $3 \mathrm{H}, J=7.0 \mathrm{~Hz}), 1.25(\mathrm{t}, 3 \mathrm{H}, J=7.0 \mathrm{~Hz}), 2.97(\mathrm{~s}, 3 \mathrm{H}), 3.46-3.52$ $(\mathrm{m}, 1 \mathrm{H}), 3.67-3.79(\mathrm{~m}, 3 \mathrm{H}), 3.98(\mathrm{~d}, 1 \mathrm{H}, J=11.0 \mathrm{~Hz}), 4.05(\mathrm{dd}$, $1 \mathrm{H}, J=3.7,7.6 \mathrm{~Hz}), 4.25(\mathrm{~d}, 1 \mathrm{H}, J=3.6 \mathrm{~Hz}), 4.30(\mathrm{dd}, 1 \mathrm{H}, J=$ $4.4,11.0 \mathrm{~Hz}), 4.62,4.68(\mathrm{~d}, 2 \mathrm{H}, J=11.8 \mathrm{~Hz}), 4.75(\mathrm{~d}, 1 \mathrm{H}, J=$ $7.6 \mathrm{~Hz}), 5.12(\mathrm{~d}, 1 \mathrm{H}, J=4.3 \mathrm{~Hz}), 7.31-7.38(\mathrm{~m}, 5 \mathrm{H}) ;{ }^{13} \mathrm{C} \mathrm{NMR}$ $\left(100 \mathrm{MHz}, \mathrm{CDCl}_{3}\right) \delta 15.1,15.2,38.3,61.5,63.0,71.4,72.5,79.9$, $81.1,81.8,100.0,127.7,127.9,128.3,137.1$. Anal. Calcd for $\mathrm{C}_{17} \mathrm{H}_{26} \mathrm{O}_{7} \mathrm{~S}:$ C, 54.53; H, 7.00. Found: C, 54.76; H, 6.91.

2,5-Anhydro-4-azido-3- $O$-benzyl-4-deoxy- $\alpha$-L-arabinose Diethyl Acetal (14). To a solution of crude mesylate $\mathbf{1 3}(88 \mathrm{mg}, 0.23$ mmol) in dry DMF (3 mL) were added $\mathrm{NaN}_{3}(91 \mathrm{mg}, 1.41 \mathrm{mmol})$ and anhydrous $\mathrm{NH}_{4} \mathrm{Cl}(23 \mathrm{mg}, 0.44 \mathrm{mmol})$. The mixture was heated to $120{ }^{\circ} \mathrm{C}$ and stirred at these conditions for about $20 \mathrm{~h}$ in a dark room. The reaction was monitored by TLC (3:1 petroleum etherEtOAc) until all starting material disappeared, and then the mixture was diluted with water and extracted with EtOAc $(4 \times 10 \mathrm{~mL})$. The organic phase was dried over anhydrous $\mathrm{Na}_{2} \mathrm{SO}_{4}$ and concentrated. Purification of the residue by silica gel column chromatography (3:1 petroleum ether-EtOAc) gave $\mathbf{1 4}(54 \mathrm{mg}, 71 \%$ for two steps) as a syrup: $[\alpha]^{25} \mathrm{D}+106\left(c 1.3, \mathrm{CHCl}_{3}\right) ;{ }^{1} \mathrm{H}$ NMR $(400$ $\left.\mathrm{MHz}, \mathrm{CDCl}_{3}\right) \delta 1.18(\mathrm{t}, 3 \mathrm{H}, J=7.0 \mathrm{~Hz}), 1.24(\mathrm{t}, 3 \mathrm{H}, J=7.0 \mathrm{~Hz})$, $3.41-3.45(\mathrm{~m}, 1 \mathrm{H}), 3.66-3.77(\mathrm{~m}, 3 \mathrm{H}), 3.83(\mathrm{dd}, 1 \mathrm{H}, J=4.5,7.8$ $\mathrm{Hz}), 3.90(\mathrm{dd}, 1 \mathrm{H}, J=4.0,7.7 \mathrm{~Hz}), 3.98(\mathrm{dd}, 1 \mathrm{H}, J=7.7,8.5$ $\mathrm{Hz}), 4.04(\mathrm{dd}, 1 \mathrm{H}, J=4.3,8.5 \mathrm{~Hz}), 4.19(\mathrm{t}, 1 \mathrm{H}, J=4.3 \mathrm{~Hz}), 4.66$ $(\mathrm{d}, 1 \mathrm{H}, J=11.2 \mathrm{~Hz}), 4.76(\mathrm{~d}, 1 \mathrm{H}, J=7.7 \mathrm{~Hz}), 4.82(\mathrm{~d}, 1 \mathrm{H}, J=$ $11.2 \mathrm{~Hz}), 7.31-7.41(\mathrm{~m}, 5 \mathrm{H}) ;{ }^{13} \mathrm{C} \mathrm{NMR}\left(100 \mathrm{MHz}, \mathrm{CDCl}_{3}\right) \delta 15.2$, 15.3, 61.4, 62.0, 62.8, 68.4, 74.2, 79.7, 80.7, 100.4, 127.6, 127.7, 128.2, 137.6. HRFABMS calcd for $\mathrm{C}_{16} \mathrm{H}_{23} \mathrm{~N}_{3} \mathrm{O}_{4} 321.1689$, found 322.1660 $(\mathrm{M}+\mathrm{H})^{+}$. Anal. Calcd for $\mathrm{C}_{16} \mathrm{H}_{23} \mathrm{~N}_{3} \mathrm{O}_{4}$ : C, 59.80; $\mathrm{H}$, 7.21. Found: C, 59.57; H, 7.29.

2,5-Anhydro-4-azido-3- $O$-benzyl-4-deoxy- $\alpha$-L-arabinose (15). The acetal 14 (310 mg, $0.96 \mathrm{mmol})$ was dissolved in $\mathrm{CH}_{2} \mathrm{Cl}_{2}(3$
$\mathrm{mL})$, and aqueous $50 \%$ trifluroacetic acid $(1 \mathrm{~mL})$ was added. The reaction progress was monitored by TLC $(2: 1$ petroleum etherEtOAc) until all $\mathbf{1 4}$ was consumed, the mixture was neutralized with saturated aqueous sodium carbonate and further extracted with $\mathrm{CH}_{2} \mathrm{Cl}_{2}(3 \times 20 \mathrm{~mL})$, and the combined organic layer was washed with brine, dried over $\mathrm{Na}_{2} \mathrm{SO}_{4}$, and concentrated to dryness. Purification of the residue by silica gel column chromatography (2:1 petroleum ether-EtOAc) gave aldehyde $\mathbf{1 5}(215 \mathrm{mg}, 90 \%)$ as a syrup: $[\alpha]^{25} \mathrm{D}+25\left(\mathrm{c} 0.2, \mathrm{CHCl}_{3}\right) ;{ }^{1} \mathrm{H} \mathrm{NMR}\left(400 \mathrm{MHz}, \mathrm{CDCl}_{3}\right)$ $\delta 3.99-4.08(\mathrm{~m}, 3 \mathrm{H}), 4.30(\mathrm{dd}, 1 \mathrm{H}, J=2.5,7.1 \mathrm{~Hz}), 4.50(\mathrm{dd}$, $1 \mathrm{H}, J=4.5,7.1 \mathrm{~Hz}), 4.66,4.70(2 \mathrm{~d}, 2 \mathrm{H}, J=11.6 \mathrm{~Hz}), 7.31-7.39$ $(\mathrm{m}, 5 \mathrm{H}), 9.66$ (br d, $1 \mathrm{H}, J=4.5 \mathrm{~Hz}) ;{ }^{13} \mathrm{C} \mathrm{NMR}\left(100 \mathrm{MHz}, \mathrm{CDCl}_{3}\right)$ $\delta$ 60.9, 70.4, 73.6, 81.4, 82.3, 127.9, 128.2, 128.5, 136.5, 200.4; HRFABMS calcd for $\mathrm{C}_{12} \mathrm{H}_{13} \mathrm{~N}_{3} \mathrm{O}_{3}$ 247.0957; found 248.0931 (M $+\mathrm{H})^{+}$. Anal. Calcd for $\mathrm{C}_{12} \mathrm{H}_{13} \mathrm{~N}_{3} \mathrm{O}_{3}$ : C, 58.29; $\mathrm{H}, 5.30$. Found: C, 58.51; H, 5.23.

Synthesis of Olefin 16. To a precooled $\left(-40{ }^{\circ} \mathrm{C}\right)$ solution of Wittig salt $\mathrm{C}_{13} \mathrm{H}_{27} \mathrm{Ph}_{3} \mathrm{P}^{+} \mathrm{Br}^{-}$(61 mg, $\left.0.11 \mathrm{mmol}\right)$ in THF $(1.5 \mathrm{~mL})$ was slowly added $n$-BuLi $(2.5 \mathrm{M}$ in hexane, $50 \mu \mathrm{L}, 0.12 \mathrm{mmol})$ under $\mathrm{N}_{2}$ protection. The orange solution was stirred at these conditions for about $20 \mathrm{~min}$, at the end of which time, a solution of 15 ( $25 \mathrm{mg}, 0.1 \mathrm{mmol})$ in dry THF $(3 \mathrm{~mL})$ was dropwise added under $\mathrm{N}_{2}$ protection. The mixture was stirred at this temperature for another $30 \mathrm{~min}$, then allowed to warm to room temperature and quenched by saturated $\mathrm{NH}_{4} \mathrm{Cl}(0.2 \mathrm{~mL})$. The mixture was diluted with water and extracted with EtOAc $(3 \times 20 \mathrm{~mL})$. The combined organic phase was dried over anhydrous $\mathrm{Na}_{2} \mathrm{SO}_{4}$ and concentrated to dryness. Purification of the residue by silica gel column chromatography (9:1 petroleum ether-EtOAc) gave $\mathbf{1 6}$ (36 $\mathrm{mg}, 86 \%, \mathrm{Z} / E>10: 1)$ as a syrup. Selected $Z$-isomer: ${ }^{1} \mathrm{H}$ NMR $\left(400 \mathrm{MHz}, \mathrm{CDCl}_{3}\right) \delta 0.88(\mathrm{t}, 3 \mathrm{H}, J=7.1 \mathrm{~Hz}), 1.20$ (br s, 20H), $2.07-2.09(\mathrm{~m}, 2 \mathrm{H}), 3.88-3.97(\mathrm{~m}, 3 \mathrm{H}), 4.11(\mathrm{t}, 1 \mathrm{H}, J=5.0 \mathrm{~Hz})$, $4.62,4.70(2 \mathrm{~d}, 2 \mathrm{H}, J=11.8 \mathrm{~Hz}), 4.71-4.72(\mathrm{~m}, 1 \mathrm{H}), 5.65-5.73$ $(\mathrm{m}, 2 \mathrm{H}, J=11.0 \mathrm{~Hz}), 7.29-7.37(\mathrm{~m}, 5 \mathrm{H}) ;{ }^{13} \mathrm{C} \mathrm{NMR}(100 \mathrm{MHz}$, $\left.\mathrm{CDCl}_{3}\right) \delta 14.0,22.6,27.7,29.2,29.3,29.4,29.5,29.6,31.8,61.5$, 68.6, 73.3, 75.8, 80.4, 124.9, 127.7, 127.8, 128.3, 135.0, 137.4; HRFABMS calcd for $\mathrm{C}_{25} \mathrm{H}_{39} \mathrm{~N}_{3} \mathrm{O}_{2} 413.3042$, found 414.3068 (M $+\mathrm{H})^{+}$. Anal. Calcd for $\mathrm{C}_{25} \mathrm{H}_{39} \mathrm{~N}_{3} \mathrm{O}_{2}$ : C, 72.60; H, 9.50. Found: C, 72.35; H, 9.42 .

Synthesis of Pachastrissamine (Jaspine B) 1. A mixture of olefin 16 (42 mg, $0.1 \mathrm{mmol})$ and $\mathrm{Pd}(\mathrm{OH})_{2} / \mathrm{C}(10 \%$ content, $10 \mathrm{mg})$ in $\mathrm{MeOH} / \mathrm{EtOAc}(1: 1 \mathrm{v} / \mathrm{v}, 6 \mathrm{~mL})$ was bubbled into $\mathrm{H}_{2}$ at a flow rate of $100 \mathrm{~mL} / \mathrm{min}$ at room temperature and 1 atm pressure. The hydrogenation was kept at these conditions for about $5 \mathrm{~h}$, at the end of which time TLC (4:1 EtOAc/methanol) showed only one product generated. The $\mathrm{Pd}(\mathrm{OH})_{2} / \mathrm{C}$ was filtered, and the filtrate was concentrated. The residue was purified on a short silica gel column, which was pre-eluted with methanol containing $2 \% \mathrm{Et}_{3} \mathrm{~N}$ (v/v) using 4:1 EtOAc/methanol as eluent to furnish target compound 1 (28 mg, 92\%) as a white solid: $[\alpha]^{25} \mathrm{D}+7\left(c 0.2, \mathrm{CHCl}_{3}\right) ;{ }^{1} \mathrm{H}$ NMR $\left(400 \mathrm{MHz}, \mathrm{CD}_{3} \mathrm{OD}\right) \delta 0.89(\mathrm{t}, 3 \mathrm{H}, J=7.0 \mathrm{~Hz}), 1.26-1.45(\mathrm{~m}$, $24 \mathrm{H}), 1.60-1.65(\mathrm{~m}, 2 \mathrm{H}), 3.70(\mathrm{dt}, 1 \mathrm{H}, J=3.5,6.8 \mathrm{~Hz}), 3.79(\mathrm{dd}$, $1 \mathrm{H}, J=4.8,7.9 \mathrm{~Hz}), 3.82-3.93(\mathrm{~m}, 2 \mathrm{H}), 4.23(\mathrm{dd}, 1 \mathrm{H}, J=3.5$, $4.8 \mathrm{~Hz}) ;{ }^{13} \mathrm{C} \mathrm{NMR}\left(100 \mathrm{MHz}, \mathrm{CD}_{3} \mathrm{OD}\right) \delta 14.5,23.7,27.2,29.7$, 30.5, 30.7, 30.8, 30.9, 33.1, 54.3, 68.9, 70.9, 84.4. HRFABMS calcd for $\mathrm{C}_{18} \mathrm{H}_{37} \mathrm{NO}_{2}$ 299.2824, found $300.2856(\mathrm{M}+\mathrm{H})^{+}$.

Acknowledgment. This work was supported by National Basic Research Program of China (2003CB415001), NNSF of China (30330690), and NIH of the US (HL62244).

Supporting Information Available: Detailed experimental procedures and spectral data for compounds 1, 7-9, and 11-16. This material is available free of charge via the Internet at http://pubs.acs.org.

JO051644Y 